\title{
How do French College Students Evaluate Their Social Integration and Transversal Skills and What Affects Their Evaluation?
}

\author{
Julien Berthaud \\ University of Burgundy, France
}

\begin{abstract}
This research, as a part of a PhD thesis in educational sciences relates to the social network and the transversal skills developed by the Bachelor's degree students ("Licence") in a French college. Overall, this work aims at identifying and estimating origins and effects of student social integration and transversal skills within the college careers. Four areas of student social integration and ten skills stemming from a reference table are measured by an original questionnaire. In this paper, the first preliminary results of this work are presented and reveal the influence of various personal and contextual factors on the integration and skills scores stated by students.
\end{abstract}

\section{Introduction}

Educational research began to focus on students interpersonal and social relationships from the $70 \mathrm{~s}$ [1], with the first models using the concept of social integration exposing the importance of interactional process to explain students careers, in addition to known individual and contextual factors.

More recently, interest for non academic skills concept emerged from research works putting forward that some kind of behaviors could be sociologically or economically valued, beyond the explicitly aimed abilities, estimated and validated by school institutions [2], [3].

This article is a part of a thesis work which aims to these two streams of education research as having prospects to evaluate their sources and their respective effects, but also to explain more precisely the student success career at college, where the influence of many factors is already known, but a significant portion remains unexplained.

\section{Theoretical framework}

\subsection{Social integration}

The concept of social integration at college particularly initiated in Tinto's studies [4] [5] has been extensively investigated, demonstrating its significant effect on student retention [6] [7].
However, there is no consensus about the conceptualization of this explanatory factor, several authors approaching it differently. On the one hand social integration is measured by the commitment and satisfaction in relationships with other students and academic staff using congruence scales [5], [8], [9]. On the other hand the nature of social relations and their frequency are emphasized, giving to see a more quantitative measure of integration [10], [11]. Some authors think that research focuses on the student's perception and satisfaction of their college integration, which refers only to one aspect of the concept [7]. Others suggest that qualitative aspects such as perception and satisfaction are needed to address the student social integration, even more important than the purely quantitative aspects such as the extent of the network [11].

It also appears that Tinto's model and many of those who are inspired are based on a distinction between different forms of integration, which social integration is opposed or contiguous to one or more types of non-social integration: academic integration [4], [10], institutional integration [41], [42], university integration [42], school integration [41] or vocational integration [43]. Whatever the distinction between these various forms of integration, two dimensions should be considered: a social dimension and a school or academic dimension. Although it is difficult to consider that social integration is independent from other forms of integration at college, it is nevertheless possible to isolate it because it relies primarily on social interactions. Although they do not exclude the role of social interactions, the other forms of integration (school, academic, institutional, vocational), are however based on other aspects, like institutional and academic ones (performances, institutional functioning, etc.), which are less influenced by the weight of social interactions [43], [42].

Furthermore, authors approach differently the network which is associated interactions and relationships of students. Sometimes teachers or other academic staffs are included in the network [50], and sometimes they are not [51]. Although it is undoubtedly influential in the global process of students integration at college, the social sphere 
formed by teachers and other university staffs, nevertheless refers to a social group defined by characteristics (in terms of age, status or social position) and motivations which are necessarily different from students ones. Similarly, interactions with teachers can be perceived by students as a help or support for their studies, and so they are more related to the pedagogical relationship than a social relationship.

Integrative models are used to explain student's success and / or persistence [5], [16], [17], [18] and also highlighted that social integration is influenced by other factors. These are related to the training context [19], [1], the level of education [20], individual factors such as gender, age or even the school past [10], but especially the social origin [21], [22], [23]. Various studies also show that taking independence from family home is associated with specific student sociability, and especially for students who have their own lodging because they faced with loneliness [44]. Also taking into account the conditions of studies, including the use of a parallel employed activity, can explain than student get involved more or less in social interactions and social activities, which defines the kind of college experience [6], [24].

Some authors reports that refine the student social integration measurement is necessary [7]. The social integration of students include both qualitative and quantitative aspects, some giving more credit to the first than the latter [11], but the focus on one or the other is usually pointed as a limit [7]. It is appropriate to separate the measures related to the perception of those related to behaviors, since these are two distinct kinds of information [46], but it should also be considered that these are the parts of a single process because perception and behaviors are evolving in the same sense. The social integration concept can be paired with other terminologies used in research, such as the sense of belonging or affiliation to a group [12], the social adjustment [13], the support network [14] or the social support. This last concept seems also bring together the different dimensions of social integration put forward in the studies, as may be defined by both the size of the support network, the support behavior within the network and the subjective judgment of support [15].

In this study, social integration is defined as the sum of these three complementary areas: the characteristics of the student network, the intranetwork behaviors and the perceived quality of the network. Thus we adapt the three-dimensional conception of social support used by Ruiller [45] and inspired by Barrera et al. [39], which defines the concept as the sum of structural dimension, functional dimension and subjective dimension. Moreover, some authors reports that the social integration origins are not always clearly identified [25], although it seems possible to explain integration differences between students from individual and contextual indicators. Thus can we establish a typology of student social integration especially with regard to the conditions of studies and particularly the exercise of an employed activity, which can be imagined concurrent to both college studies also social integration?

\subsection{Transversal skills}

Always as a debated subject, skills in scientific literature globally designate the capacities that can be mobilized at different levels: "know", "know how" and "know how to be", as the Stroobants threesome of skills [26]. Terminology employed on this research object which still under construction generates debates. For some authors skill mastery requires the mobilization and / or the activation of several knowledge in a given situation or context [27], which induces a sense of transversality between different types of knowledge. In college the development of skills-based approach especially results from a growing desire to professionalize students [28], leading to the development of teaching practices articulating between education and employment. Also goals are to consider both purely disciplinary skills but also more generic skills, leading to the idea of transversality between academic and workplace environment.

These non-academic skills are often defined by default, as opposed to disciplinary and academic skills, and described differently depending on various referential that invest different fields of skills. The consideration and the place of these nonacademic skills at European level are reflected in referential, qualifying standards and to define qualifications [29].

During the first days of studies on non-academic skills in school and professional careers, many examples of non-academic skills were given by different participants [47]: interpersonal skills, use and management of emotions, endurance, adaptability to difficult conditions, constraints management, compliance, autonomy, self-education, ability to work in an emergency, mobilization of networks, organization and collaboration, selfconfidence. It shows a rich and diverse range of abilities, all the more interesting as it relates to various categories of people, both professionals and students. This reflects the lower dissociation between education and employment initiated by the institutions and the organizations supporting the competency-based approach. As part of the Tuning Project [28], a survey among universities identified a number of skills that students consider necessary to ensure their employability. Among them are mentioned: analytical reasoning, problem solving, adaptability to new situations, concern for quality, autonomous work, teamwork, organization and 
planning, oral and written communication. Thus we note that many of these skills are also qualifying and recognized within a strictly academic curriculum. Also the idea of transversality between institutional certification and professionalism shines on the usefulness and the use of these skills.

Factors of transversal skills development are not much investigated but research questions the place where they are acquired and where they manifest. For example, research on social skills tends to consider that they are probably linked with family, social and educational experiences. For others, the simulation through the exercise of professional activity turns out to be the crucial complement to formal disciplinary contents that provides education, in order to acquire the standards of a profession or a workplace [48]. The formative nature of the experiment is highlighted and implies that learning and thereby skill is the simple result of the manipulation of knowledge of any kind. But this is not a refutation of the idea that school and more broadly the educational system represents a place of development of necessary provisions for the integration into working life, on the sidelines of disciplinary contents

The parallel between education and employment transcribed in the concept of transversal skills invites to hypothesize that student who combines work and studies would be more likely to present these skills. Moreover, it appears that the employed activity carried on by students in parallel of their studies, even remote from studies curriculum, is later appreciated on the labor market, both in terms of skills developed like professional experience initiating professional career [30]. In addition, many studies have demonstrated the effect of noncognitive skills on the pay level [31], [32], [33] and the recruitment process [34], [3], employers pretend assign more value to certain attitudes such as communication and teamwork than criteria such as number of study years or academic performance.

The skill concept considered in this research isn't based on a classification into three types of skills which correspond three separate types of knowledge. But skill is seen as the process involving the mobilization and / or activation of different types of knowledge. In this regard, the skill development does not correspond to the learning of a standard behavior but rather a "scalable cognitive organization to provide behavioral answers adjusted according to the characteristics of each situation" [28; p.17]. The herein used notion of transversality particularly transcribed that skill can be mobilized in different contexts and different situations: both within academic context than professional or social one.

\section{Method}

One goal of this research, which is considered here, is to identify the sources, i.e. the factors that influence student social integration and transversal skills. Along these lines, the influence of sociodemographic characteristics, educational context also studies conditions is evaluated.

\subsection{Sample and procedure}

The study population refers to students enrolled in 1st, 2nd and 3rd year of general "Licences" (bachelor's degree), i.e. students who potentially presents the greatest variability in terms of social integration, study conditions but also study achievement [35], [36].

An online questionnaire was disseminated through mailing list to all Licence degree students from the University of Burgundy in December 2014. 1365 valid cases were collected with a return rate of $15 \%$.

Sample is composed of $66 \%$ women, $40 \%$ of students are in first grade of Licence degree, $32 \%$ are in second grade and $28 \%$ in third grade. The vast majority is French nationality $(97 \%)$ and is from general baccalaureates $(85 \%)$, then $10 \%$ have a technological or vocational baccalaureate. The disciplinary fields represented are from $26 \%$ in the human sciences field, $24 \%$ in economy-lawmanagement field, $24 \%$ in sciences field, $18 \%$ in letters-parlance-languages field and $8 \%$ of sports science (STAPS). The average age is 20 years. $27 \%$ are living in the family home, $51 \%$ are living in an independent lodging and $22 \%$ are living in student hostel. Finally, half of students are scholarship holders and one quarter of them have an employed activity alongside their studies.

\subsection{Instrument}

To carry out this project, an original measurement tool was developed. As shown on the figure 1, it is based firstly on a conceptualization of social integration both quantitative and qualitative into three parts relating to structural, functional and subjective dimensions and which are: the characteristics of the student network, intra-network behaviors and the perceived quality of the network. Special interest was ported to the need to distinguish among the behaviors adopted by the student network the internal interactions related to student work and the purely social interactions called external interactions, another dimension of social integration which must also be considered for approach the concept as a whole [37], [38]. Similarly, the perceived quality of the network comprises two dimensions which are the value granted on student network and exchanges, and the perceived social support. For this purpose, the questionnaire is inspired by approaches adopted in literature and existing tools, including the "Inventory of Socially 
Supportive Behaviors Scale" of Barrera et al. [39] which measures social support. Since this research is interested in the influence of the peer group, so we are talking about student social integration which excludes faculty and others institutional staffs.

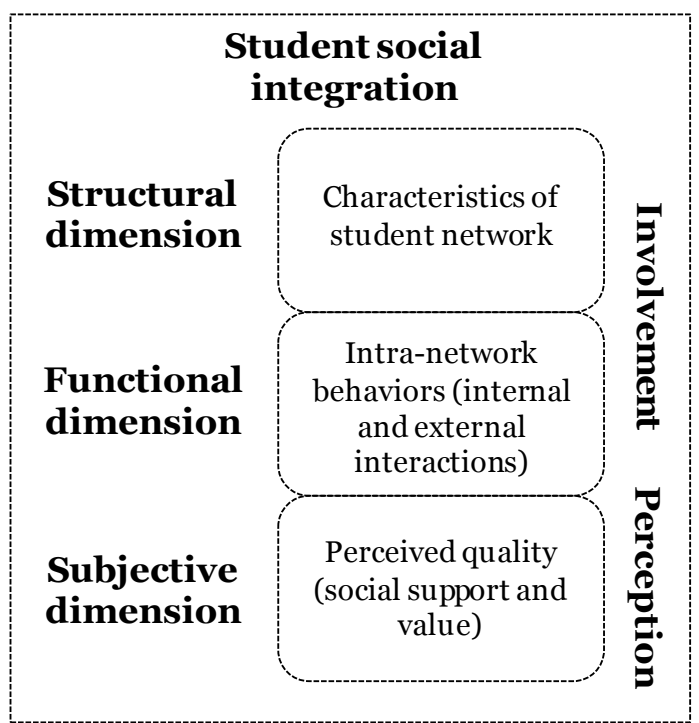

Figure 1. Dimensions and components of student social integration

The choice of evaluated transversal skills results from the proposed classification in the "Passeport Avenir" referential of behavioral skills [40] which provides a five levels scale depending upon mastery degree for each skill. These levels are described in detail by examples of response to a given situation. These elements have been resumed in order to provide each level of each scale of the ten selected skills which most transcribe the concept of transversality between professional and academic environment: adaptability, ongoing learning, communication, creativity, stress management, initiative, decision making, analytical reasoning, determination for results and teamwork.

Alongside social integration and transversal skills, the measurement tool includes many other checking indicators related to sociodemographic characteristics, educational background, academic commitment, study conditions and educational context.

\subsection{Data analysis}

To quantify the variability of social integration and transversal skills between students, scores were calculated from the scales presented in the questionnaire: four scores for social integration corresponding to the abovementioned subdimensions (internal interactions, external interactions, support provided, network value) and ten scores related to the ten skills assessed. These scales have been subjected to reliability tests
(Cronbach's alpha) whose indices range 0.6 to 0.9 for social integration scores and range 0.6 to 0.8 for skills scores.

Correlation and mean comparisons were performed to test the effect of demographic and contextual factors on social integration scores and transversal skills scores. Insofar as only two scores follow a normal distribution, non-parametric tests were preferred: the Mann-Whitney test, the KruskalWallis test, and the Jonckheere-Terpstra test.

\section{First results}

Generally for student social integration, students are reporting much higher scores regarding the value assigned to the network ( $\bar{X}=22.9 / 32$ ) i.e. they provide significant value to network members and relationships, and they feel it helps them in their studies, as their personal development and are fairly well integrated into college. However, they report much lower scores for internal interactions (studious activities, $\quad \bar{X}=12.4 / 32$ ), social support provided by the network ( $\bar{X}=9.8 / 32)$ and external interactions (social activities, $\bar{X}=5.9 / 32$ ). This means that although interactions and support received are not very diversified and / or very recurrent, students will place it great integrative value.

Regarding transversal skills scores, students say the most competent to teamwork ( $\bar{X}=21.4 / 30)$, creativity ( $\bar{X}=21.2 / 30$ ), analytical reasoning and decision making ( $\bar{X}=21 / 30)$. They feel less competent with determination for results ( $\bar{X}=16.8 / 30$ ), adaptability ( $\bar{X}=17.1 / 30)$ and stress management ( $\bar{X}=18.2 / 30$ ).

Comparing means by gender, we can note that men have higher means on almost all of transversal skills scores except initiative and teamwork. Conversely, women have higher means on all social integration scores except for external interactions. Non-parametric tests revealed significant differences $(p<.05)$ by gender for analytical reasoning and communication, and other highly significant $(\mathrm{p}<.01)$ for decision-making, management of stress, internal interactions and received support. One of the few significant differences noted $(\mathrm{p}<.1)$ for initiative and creativity.

The age of students appears significantly correlated $(\mathrm{p}<.01)$ with three skills: initiative, adaptability and ongoing learning. The relationship is positive which means that the scores increase with increasing age. Age also appears to be very significantly related to the four scores of student social integration, but this time the relationship is negative which means that older students report significantly lower scores for social integration. This result confirms the studies that have shown that student sociability is more mobilized by young students because it allows them to transition to 
adulthood and represents a help for studies. In contrast, the kind of lodging which is described in literature as influential on social integration [24] reveals no significant difference on integration scores depending on whether students lives with family or in an independent lodging or in residence hall or else student hostel.

The educational context seems to influence more strongly the scores reported by students. Nonparametric tests were performed to determine the influence of educational level (1st, 2nd or 3rd grade), disciplinary field (human sciences, sciences, lawmanagement-economics, parlance-languages-letters, sports science) and lectures proportion where the student number is the most important, compared to directed works where smaller numbers are similar to classes in secondary education. Thus it appears significantly increases the higher the level is the greater students assign value to their network $(\mathrm{p}<.05)$, the larger internal interactions are $(\mathrm{p}<.05)$, and the greater students consider themselves competent in analytical reasoning $(\mathrm{p}<.01)$, initiative and ongoing learning $(\mathrm{p}<.01)$. Conversely, the higher the level of education is high unless the students consider themselves knowledgeable about decision making $(\mathrm{p}<.01)$ and stress management $(\mathrm{p}<.05)$. Furthermore, the disciplinary field significantly affects virtually all scores except for stress management and determination for results. The effect is also very significant $(\mathrm{p}<.01)$ on received support, external interactions and teamwork, analytical reasoning, decision making, initiative and communication. Students enrolled in human sciences field declare the highest scores for four skills: teamwork, analytical reasoning, initiative and adaptability. However, they are those who attribute the least value to their student social network. Conversely, science field students are those who attribute the highest value to their network but have the lowest means for three skills (teamwork, determination for results and ongoing learning) and external interactions else perceived support. Students enrolled in management-economics-law field only present the highest scores for decision making and internal interactions. Students enrolled in parlancelanguages-letters field have the lowest scores for stress management but say themselves the most competent to determination for results, creativity, communication and ongoing learning. These are also those who believe receive more support from their student social network. Finally, sports science students appear atypical, indeed they are most at lower means for six among the ten skills assessed and internal interactions what might be explained by the strong competitive spirit attributed to sport environment. Conversely, they are the most competent students in stress management else whose report the greatest external interactions (more than two points above the other groups). The last influent indicator relating to educational context is the organization of teaching (understood from the proportion of lectures over directed works). This factor influences significantly $(p<.01)$ the value attributed to student social network: more the share of lecturers increases relative to the share of directed works more the network value decreases indicating a lower network and interactions quality among students who most often attend courses in amphitheater with large numbers of students. This learning environment is rightly recognized as few beneficial to social integration and exchanges between students. The analysis was reproduced considering the number of course hours taught in each formation but revealed no significant impact.

Finally the comparison was made between students who engage in employed activity alongside their studies and those who do not work with the assumption that the first ones are likely to have higher scores of transversal skills because of their professional experience whereas lower scores in social integration because of their harder schedule. Analysis will partially confirm this assumption because working students indeed have higher scores to other students across all transversal skills except for creativity but these differences are not significant or not much significant $(\mathrm{p}<.1)$ concerning initiative and ongoing learning. Regarding to social integration only the perceived social support score is lower among working students and no significant differences in means are raised about the four integration scores.

\section{Conclusion}

These early exploratory results provide some answers regarding factors affecting transversal skills and social network developed by French Licence degree students. Although on one hand these results demonstrate by a clear enough way disparities between students through level of education and disciplinary field, suggesting that some skills else some aspects of social integration are strongly associated with studies progress and disciplinary field (where science sports students appears atypical), other indicators related to study conditions and whose influence was assumed finally appear few explanatory: employed activity, lodging type as well as the organization of teaching.

It remains that these preliminary analysis have revealed disparities, both in terms of transversal skills that student social integration, which calls for further and refine analysis.

Furthermore these two concepts seem to be influenced by the same factors which invite us to consider the existence of a link. As an scalable process depending on the age of students and their position in the life cycle, the student social integration is a means made to serve the transitions at 
which students face: school transition, social transition and identity transition. In parallel the investigations conducted by the OECD (Organisation for Economic Co-operation and Development) that assess student skills such as adaptability, communication or initiative present these skills as "ones for life", defined as those which everyone must have for insertion into the social and professional life [49]. Thus student social integration and transversal skills share this formative function among youth since they enables them to acquire status of adult which are able to integrate into society. The nature of the link between these two kinds of data is worth investigating.

Finally, their effects on student success career (examination success else grades obtained) remain to understand within integrative models which is the second main objective of this research. Aims particularly to determine whether there are mediating relations between transversal skills and student social integration in the explanation of student achievement.

\section{References}

[1] A. Coulon, and S. Paivandi, "Etat des savoirs sur les relations entre les étudiants, les enseignants et les IATOSS dans les établissements d'enseignement supérieur", Rapport pour l'Observatoire national de la vie étudiante, 2008.

[2] J. J. Heckman, and T. D. Kautz, "Hard evidence on soft skills”, Labour Economics, 19, n4, 2012, pp.451-464.

[3] M. M. Robles, "Executive perceptions of the top 10 soft skills needed in today's workplace", Business Communication Quarterly, 75(4), 2012, pp.453 465.

[4] V. Tinto, "Dropout from higher Education: A theorical synthesis of recent research", Review of Educational Research, 45(1), 1975, pp.89-125.

[5] V. Tinto, Leaving college: Rethinking the causes and cures of student attrition (2nd ed.), Chicago: The University of Chicago Press, 1993.

[6] F. Dubet, "Dimensions et figures de l'expérience étudiante dans l'université de masse", Revue française de sociologie, XXXV, 1994, pp.511-532.

[7] J. Schmitz, M. Frenay, S. Neuville, G. Boudrenghien V. Wertz, B. Noël, and J. Eccles, "Etude de trois facteurs clés pour comprendre la persévérance à l'université", Revue française de pédagogie, 172, 2010, pp.43-61.

[8] S. Larose, N. Soucy, A. Bernier, and R. Roy, "Exploration des qualités psychométriques de la version française $\mathrm{du}$ Student Adaptation to College Questionnaire", Mesure et évaluation en éducation, 19(1), 1996, pp.69-94.
[9] S. Neuville, M. Frenay, B. Noel, and V. Wertz, "La persévérance et la réussite dans l'enseignement supérieur : confrontation $\mathrm{du}$ modèle de l'intégration sociale et académique de Tinto et du modèle expectancy-value d'Eccles et Wigfield", In S. Neuville, M. Frenay, B. Noel and V. Wertz (Dir.), Persévérer et réussir à l'université (pp.107-134), Louvain : Presses universitaires de Louvain, 2013.

[10] D. W. Chapman, and E. T. Pascarella, "Predictors of academic and social integration of college students", Research in Higher Education, vol.19, n³, 1983, pp.295322.

[11] K. Mamiseishvili, "International Student Persistence in U.S. Postsecondary Institutions", Higher Education, vol. 64, n 1,2012 , pp.1-17.

[12] R. Mucchielli, Le travail en groupe, Paris : Éditions ESF, 1980.

[13] S. Hurtado, D. F. Carter, and A. Spuler, "Latino student transition to college: Assessing difficulties and factors in successful college adjustment", Research in Higher Education, 37(2), 1996, pp.135-157.

[14] D.L. Rock, K.E. Green, B.K. Wise, and R.D. Rock, "Social Support and Social Network Scales: A Psychometric Review", Research in Nursing and Health, n7, 1984, pp.325-332.

[15] L. Beauregard, and S. Dumont, " La mesure du soutien social”, Service social, vol. 45, n 3, 1996, pp.5576.

[16] E. T. Pascarella, "Students' affective development within the college environment", Journal of Higher Education, 56(6), 1985, pp.640-663.

[17] A. Cabrera, M. Castaneda, A. Nora, and D. Hengstler, "The convergence between two theories of college persistence", The Journal of Higher Education, vol. 63, $\mathrm{n}^{\circ}$ 2, 1992, pp.143-164.

[18] J. Schmitz, and M. Frenay, "La persévérance en première année à l'université : rôle des expériences en classe, de l'intégration sociale et de l'ajustement émotionnel", In S. Neuville, M. Frenay, B. Noel and V. Wertz (Dir.), Persévérer et réussir à l'université (pp.83106), Louvain : Presses universitaires de Louvain, 2013.

[19] G. Felouzis, La condition étudiante, Paris: PUF, 2001.

[20] R. Boyer, C. Coridian, and V. Erlich, "L'entrée dans la vie étudiante. Socialisation et apprentissage", Revue française de pédagogie, $\mathrm{n}^{\circ} 136,2001$, pp.97-105.

[21] V. Monfort, "Les étudiants de première année à l'université et le travail scolaire. L'exemple de deux filières: sciences et AES", Thèse de troisième cycle, EHESS, 2003.

[22] S. Beaud, "Un temps élastique : étudiants des « cités » et examens universitaires", Terrain, n²9, 1997, pp.43-58. 
[23] J.P. Molinari, Les étudiants, Paris : Les Editions Ouvrières, 1992.

[24] R. Boyer, "L'entrée à l'université", In V. Erlich, A. Frickey, P. Heraux, J-L. Primon, R. Boyer and C. Coridian, La socialisation des étudiants débutants Expériences universitaires, familiales et sociales (pp.3966), Les dossiers évaluations et statistiques, MEN-DPD, $\mathrm{N}^{\circ} 115,2000$.

[25] J.M. Braxton, J.F. Milem, and A.S. Sullivan, "The influence of active learning on the college student departure process: toward a revision of Tinto's theory", Journal of Higher Education, 75(5), 2000, pp. 569-590.

[26] M. Stroobants, R. Bourdoncle, and L. Demailly, "Former et évaluer des compétences : des objectifs contradictoires ?", In R. Bourdoncle et L. Demailly (éds), Les professions de l'éducation et de la formation (pp.215224). Villeneuve d'Ascq (Nord): Presses Universitaires du Septentrion (Métiers de la formation), 1998.

[27] C. Le Boterf, De la compétence : Essai sur un attracteur étrange, Paris : Les Éditions d'Organisation, 1994.

[28] C. Chauvigné, and J.-C. Coulet, "L'approche par compétences : un nouveau paradigme pour la pédagogie universitaire ?", Revue française de pédagogie, n 172 , 2010, pp.15-28.

[29] S. Safourcade, "Place et rôle des soft skills dans l'enseignement supérieur", Journées d'étude sur les compétences non académiques dans les parcours scolaires et professionnels, Dijon, 2014.

[30] C. Béduwé, and J.-F. Giret, "Le travail en cours d'études a-t-il une valeur professionnelle ?", Economie et statistique, $\mathrm{n}^{\circ} 378-379,2004$, pp.55-83.

[31] C. Jencks, S. Bartlett, M. Corcoran, J. Crouse, D. Eaglesfield, et al., Who Gets Ahead? The Determinants of Economic Success in America?, New York: Basic Books, 1979.

[32] M. Barrick, and M. Mount, "The big five personality dimensions and job performance: a meta-analysis", Pers. Psychol., 44, 1991, pp.1-26.

[33] J. Rosenbaum, Beyond College for All: Career Paths for the Forgotten Half, NewYork: Russell Sage Found, 2001.

[34] M. Almlund, A. Lee Duckworth, J.J. Heckman, and T.D. Kautz, "Personality Psychology and Economics", NBER Working Paper, $n^{\circ} 16822,2011$.

[35] E. Annoot, La réussite à l'université du tutorat au plan licence, De Boeck: Collection Pédagogie en développement, 2012.

[36] G. Felouzis, Les mutations actuelles de l'université, Paris : PUF, 2003.

[37] V. Erlich, Les nouveaux étudiants. Un groupe social en mutation, Paris: Armand Colin, 1998.
[38] O. Galland, M. Clémençon, P. Le Gallès, and M. Oberti, Le monde des étudiants, Paris: PUF, 1995.

[39] M. Barrera, I.N. Sandler, and T.B. Ramsey, "Preliminary development of a scale of social support", American Journal of Community Psychology, $\mathrm{n}^{\circ}$ 9, 1981, pp.435-447.

[40] Passeport Avenir, "Référentiel des compétences comportementales", 2011.

[41] S. Larose, and R. Roy, "Modélisation de l'intégration aux études collégiales et facteurs de réussite scolaire chez les nouveaux arrivants à risqué", Rapport de recherche, Sainte-Foy : Cégep de Sainte-Foy, 1993.

[42] V. Duclos, "L'intégration universitaire et sociale d'étudiants tunisiens et marocains inscrits dans une université francophone canadienne", Revue canadienne d'enseignement supérieur, 41(3), 2011, pp.81-101.

[43] G. Tremblay, H. Bonnelli, S. Larose, S. Audet, and C. Voyer, C., "Recherche-action pour développer un modèle d'intervention favorisant l'intégration, la persévérance et la réussite des garçons aux études collégiales", CRI-VIFF, 2006.

[44] M. Bonnet, "Temporalités étudiantes: des mobilités sans qualities", Annales de la recherche urbaine, Vol. 77, 1997, pp. 63-71.

[45] C. Ruiller, "Construction d'une échelle de la perception du soutien social: premiers résultats d'une étude de cas sur un centre hospitalier", XVIIIe Congrès de l'AGRH, Fribourg, 2007.

[46] A. W. Astin, "Involvement in learning revisited: Lessons we have learned", Journal of College Student Development, 37(2), 1996, pp.123-134.

[47] S. Morlaix, J. Berthaud, A. Dirani, and A. Fanchini, "Conclusion". In J.-F. Giret and S. Morlaix (Dir.), Les compétences sociales et non académiques dans les parcours scolaires et professionnels (pp. 152-154). Dijon : Editions universitaires de Dijon, 2016.

[48] F. Sarfati, "Faut-il être compétent pour pouvoir développer ses compétences? L'exemple de la sélection à l'entrée en Master 2", Formation emploi, 130(2), 2015, pp.31-48.

[49] OCDE, "Des competences pour la vie? Principaux résultats de l'évaluation des compétences des adultes", OCDE, 2013

[50] J. B. Berger, and J. F. Milem, "The role of student involvement and perceptions of integration in a causal model of student persistence", Research in higher Education, 40(6), 1999, pp.641-664.

[51] M. A. Mannan, "An assessment of the academic and social integration as perceived by the students in the University of Papua New Guinea”, Higher Education, 41, 2001, pp.283-298. 
International Journal of Technology and Inclusive Education (IJTIE) , Volume 5, Issue 2, December 2016 